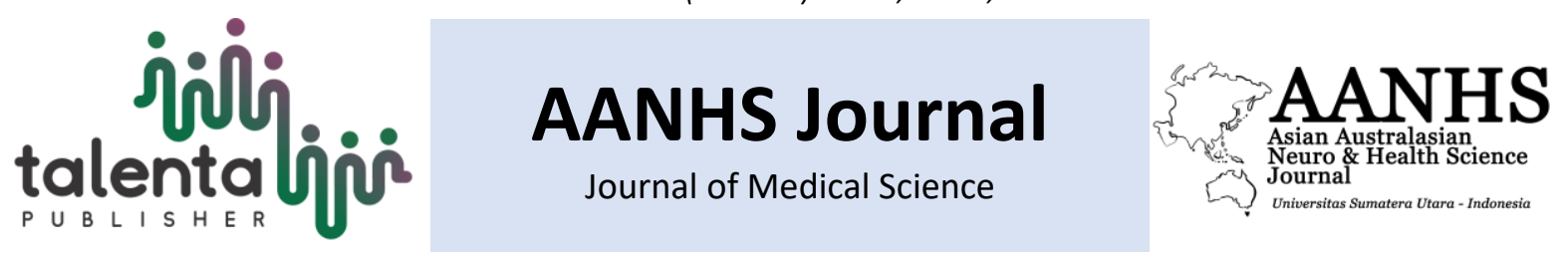

\title{
Relationship Between Waist Circumference With Frequency Of Attack And Pain Intensity In Malaysian Students Who Have Migraine
}

\author{
Muhammad Nazrul', Khairul Putra $S^{2}$ \\ ${ }^{1}$ College of Medicine, University of Sumatera Utara \\ ${ }^{2}$ Chief of Neurology Department, University of Sumatera Utara
}

\begin{abstract}
Obesity can be intergreted as an excessive accumulation of body fat which leads to health problems, including migraine. Obesity is associated with the metabolic syndrome, a pro-inflammatory, pro-thrombotic state that may contribute to headache development and progression. Stimulation of trigeminal nociceptor induced the release of pro inflammation substances especially calsitonin-gene related peptide (CGRP) and $\mathrm{P}$ substance. Those substances are found higher in migraine and obesity person. Neurogenic inflammation state was known has a big role on migraine pain. To evaluate the relationship between waist circumference with frequencies and pain intensity in Malaysian students with migraine at the University of Sumatera Utara. Observational analytic with cross sectional approach. A sample of 94 people was taken based on the total sampling technique. The data obtained are presented in tabular form and then analyzed using the Chi-square Test. Data were analyzed using univariate and bivariate with the Chi-square test. From 77 subjects of the study consisting of 11 people with migraine aura and 66 people with migraine without aura. Most of the study samples were female $(77.9 \%)$ and an average age of 20.97 years. The majority of race obtained was Malay (50.6\%), BMI whose majority was normal (58.4\%). From a 11 people with migraine aura, 7 of them had normal waist circumference and of 66 people with migraine without aura 40 of them had normal waist circumference. From Univariate and Bivariate analysis showed no significant relationship between waist circumference with the frequency of migraine attacks $(\mathrm{p}=0.489)$ and there was no significant relationship between waist circumference and the intensity of migraine pain $(\mathrm{p}=0.245)$. There is no significant relationship between waist circumference with the frequency of attacks and pain intensity in Malaysian students who experience migraine.
\end{abstract}

Keyword: Anthropometry, obesity, BMI, Migraine

Received [10 Des 2019] | Revised [26 Jan 2020] | Accepted [22 Feb 2020]

\section{Introduction}

Anthropometry is a study that measures human body parts from various dimensions, such as bones, muscles and fat tissue; Examples of anthropometric measurements include weight, height, waist circumference, hip circumference, fat thickness (biceps, triceps, suprailiac etc.), and upper arm circumference. Anthropometric measurements have several advantages, such as being able to provide information about past nutritional history, which cannot be obtained with the same evidence through other measurement methods. This measurement can be done relative

\footnotetext{
*Corresponding author at: Khairul Putra Surbakti, Chief Department Neurology, Faculty of Medicine, Universitas Sumatera Utara, Medan, Indonesia. Phone+62-8163187-374
} 
quickly, easily, and reliably using portable equipment, the availability of standardized methods, and the use of calibrated equipment.[1]

Anthropometry is also an indicator that has long been used and is often used for determined nutritional status. Anthropometric measurements in central obesity are generally carried out to see predictions of metabolic disorders. Several studies reported that anthropometric indicators of central obesity such as the ratio of hip waist circumference, and waist circumference are associated with metabolic syndrome but some studies show inconsistent results. The existence of a strong correlation between anthropometric measurements with metabolic disorders in a person is also influenced by one's metabolism, such as age, gender, race, ethnicity, religion, genetics, and others. Several studies have used anthropometric indicators in assessing the incidence of central obesity. [2]

Flegal, M., et al states, adults are called obese if they have a Body Mass Index (BMI) more or equal to 30 . BMI is assessed based on the weight formula ( $\mathrm{kg})$ divided by height squared $(\mathrm{m} 2)$, then rounded to one decimal number. [3]

$$
\text { BMI }=\text { Weight }(\mathrm{kg}) / \text { Height }^{2}\left(\mathrm{~m}^{2}\right)
$$

Nationally, the prevalence of central obesity in Indonesia in 2013 was $26.6 \%$, higher than the prevalence in 2007 (18.8\%) [4]. Some examples of anthropometric measurements are the waist circumference and the ratio of waist circumference (LP) and pelvis (RLPP). Both types of measurements can predict the existence of central obesity which is one of the risks of CVD that occurs in the majority of humans. Gharakhanlou, et al 2012 also stated that this anthropometric measurement is one of the predictors for predicting CVD, especially LP and RLPP. [5]

The World Health Organization (WHO) in 2003 stated that more than one billion adults were overweight and over three hundred million were obese. Asians have a obesity prevalence of 9.3\%. Low et al. 2009 states the prevalence of overweight and obese in developed and developing countries has increased. In 2008, an estimated 1.46 billion adults worldwide were overweight ([BMI]> $\left.25 \mathrm{~kg} / \mathrm{m}^{2}\right)$ and 502 million adults were obese (BMI> $30 \mathrm{~kg} / \mathrm{m}^{2}$ ), and it was estimated that in 2030 there were 2.16 billion adults in the world are overweight, and 1.12 billion will become obese. [6]

The prevalence of general obesity in adults nationally is $19.1 \%$ (8.8\% more BB and $10.3 \%$ obese). A total of 14 provinces have an obesity prevalence exceeding the national prevalence, namely the five provinces that have the lowest general obesity prevalence are East Nusa Tenggara, West Nusa Tenggara, West Kalimantan, West Sulawesi and South Sumatra. While the five provinces with the highest prevalence of general obesity are: East Kalimantan, North Maluku, Gorontalo, DKI Jakarta and North Sulawesi. [4]

Obesity does not only have an impact on health problems, but also requires high health care costs [7]. Obesity is also a risk factor for chronic headaches [8].Excessive body fat in obese people can trigger dangerous diseases such as type 2 diabetes mellitus, hypertension, dyslipidemia, cardiovascular disease, stroke, gallstone disease, respiratory dysfunction, and various types of cancer. [9]

There are several studies that have been discussed about obesity that play a role in migraine headaches both in terms of episodic and chronic, the frequency of migraine attacks, migraine symptoms and the intensity of the pain. Obesity is even a risk factor for migraine. [10]

Migraine is a periodic, unilateral, sometimes throbbing headache that is often found in all age ranges. Migraine headaches usually begin in early adulthood [11]. There are two types of migraine syndrome, namely migraine with aura and without aura [12]. Women are three times 
more often exposed to migraines than men. Generally the cause of migraine is caused by several factors such as hormones, nutrition, weather, stress, stress, emotional, sensory problems (cigarette smoke, perfume and others), lack of sleep, excessive sleep, fatigue and physical activity. [13]

Episodes of migraine headaches usually last around 4 - 72 hours. Nausea, vomiting, photophobia, phonophobia, and fatigue are symptoms that are often found in this disease.[14] Two theories are known about the pathophysiology of migraine, namely vasogenic and neurogenic theories. In the vasogenic theory it is hypothesized that the presence of prodormal symptoms or aura is caused by intracranial vasoconstriction and headaches caused by reactive vasodilation. In neurogenic theory, migraine is hypothesized to be a result of neuronal dysfunction due to oligemia. Oligemia is a decrease in blood flow without acute tissue damage, which occurs in shock, migraine and stroke. [15]

Migraine complaints significantly affect health and lifestyle. Almost all migraine sufferers experience a decrease both in their social activities and work capacity. [16] Costs that must come out due to absent from work and decreased performance at work are an impact which is always due to headaches or migraines. [17]

Migraine and adipose tissue are both associated with sexual dimorphism; and both have been linked to estrogen and the female hormonal life cycle. The prevalence of migraine is more common in adult women of reproductive age than men, ( 3 times greater in women than men) with an increase in the prevalence of migraine that is first seen in women at puberty and decreases in postmenopause. [18]

Stimulation by trigeminal ganglion nociceptors induces the release of proinflammatory substances especially calcitonin-gene related peptide (CGRP) and substance P, which in obese patients are known to increase. Neurogenic inflammation is thought to play an important role in the onset of migraine headaches. [19] There are other theories, namely neurovascular and neurochemical theories where when a migraine attack occurs, the trigeminal nerve secretes large amounts of CGRP (Calcitonin Gene-related Peptide). This is what causes vasodilation of multiple blood vessels, causing headaches. CGRP is a peptide that acts as a potent vasodilator. The action of CGRP is mediated by 2 receptors, namely CGRP 1 and CGRP 2. In principle, migraine sufferers who are not having an attack experience hyperexcitability of neurons in the cerebral cortex, especially in the occipital cortex, which is known from MRI recording (magnetic resonance imaging) and magnetic stimulation studies transcranial. [20]

The relationship between migraine and obesity was first evaluated in a clinical study that found obese patients were twice as likely to suffer from migraine compared to normoweight controls of the same age. Ford et al. (2008) stated that those with a lower BMI (underweight) or BMI 30 (obesity) had a higher risk of suffering from severe headaches or migraine than those who had a normal BMI (normoweight). [21] In another study, they found that the BMI group was not associated with the prevalence of migraine but the frequency of headache attacks, as headache days per month were higher in obesity and unhealthy fat groups. [22]

Research on the relationship of obesity and migraine has not been done in Indonesia. The existence of differences of opinion regarding the relationship of obesity and migraine can not be explained. However, some researchers say this difference can only be seen from the methodology used by researchers. Several studies using standard measures for height and weight: In this study, 18,968 of 162,576 (11.7\%) individuals aged 12 years and over were screened positively affected by migraine. Among individuals, the occurrence of very frequent headaches was significantly higher in obesity (8.2\%) and the unhealthy fat group (10.4\%), compared to the normal weight group (6.5\%). [22] 
Other studies also, only include height and weight based on direct information from respondents; Ford et al. Evaluated 7,601 participants and found that those who were underweight $(<18.5)$ or obese $(\mathrm{BMI} \geq 30)$ had a higher risk of experiencing severe headaches or migraines compared to those of normal weight. [23]

\section{$2 \quad$ Method}

- Research Design

The type of research used is analytic research, with a cross sectional research design, namely by making observations and short-term measurements of Malaysian students at the University of North Sumatra.

- Samples and Populations

The sample of this study were all Malaysian students in 2016, 2017, 2018 who were carrying out Bachelor's Education (S1) at the Faculty of Medicine, Faculty of Dentistry, Faculty of Pharmacy. The sampling technique in this study uses a non-probability sampling technique with a total sampling type. The sample in this study amounted to 94 people.

- Research Variables

The dependent variable in this study was the frequency of migraine attacks and the intensity of migraine pain. The independent variable is waist circumference.

- Definition of Variable Operations

Waist circumference: The magnitude of the circumference of the waist in a standing position measured at the top of the crista illiaca on the right side around the abdomen horizontally parallel to the crista illiaca

Migraine: Migraine is a periodic disorder characterized by unilateral (sometimes bilateral) headaches that can be accompanied by vomiting and visual disturbances.

Headache intensity: The degree to which head pain can be measured by several instruments adopted from the International Association for the Study of Pain.

- Research Instruments

The measurement of waist circumference is obtained by using a measuring tape with a level of accuracy of $1 \mathrm{~mm}$, with measurements on the part to be measured free of clothing measured at the respondent's normal expiration. Measurement of the frequency of attacks and the intensity of migraine pain were taken using a questionnaire in accordance with HIS Classification (Questionnaire adapted from HO K-H \& Ong BK-C). The questionnaire used to measure the dependent variable on the respondent was taken from the study entitled "The Relationship of the Use of Electronic Media to Headache in Adolescents" by Anita Surya and supplemented by the MIDAS questionnaire.

- Data analysis

All data collected is processed using a statistical software in accordance with the purpose of the study. Data were analyzed analytically (univariate) to determine the frequency distribution of 
research subjects' characteristics. Then proceed with the chi-square analysis to see the relationship between the independent and dependent variables (bivariate)

- Research Ethics

Research ethics includes informed consent, anonymity, confidentiality, and permission ethics. Ethical feasibility in this study comes from the Medical Research Ethics Commission of the Faculty of Medicine, University of North Sumatra / H. Adam Malik Hospital, Medan with number: 81 / TGL / KEPK / FK USU-RSUP HAM / 2019.

\section{$3 \quad$ Result}

Table 1. Distribution of characteristic frequencies and MIDAS of respondents

\begin{tabular}{|c|c|c|}
\hline Parameter & Frequency (n) & Percentage (\%) \\
\hline Age & $20,97 \pm 1,42$ & \\
\hline 19 & 8 & 10,39 \\
\hline 20 & 17 & 22,08 \\
\hline 21 & 17 & 22,08 \\
\hline 22 & 20 & 25,97 \\
\hline 23 & 10 & 12,99 \\
\hline 24 & 4 & 5,19 \\
\hline 25 & 1 & 1,30 \\
\hline \multicolumn{3}{|l|}{ Gender } \\
\hline Man & 17 & 22,10 \\
\hline Woman & 60 & 77,90 \\
\hline \multicolumn{3}{|l|}{ Race } \\
\hline Malay & 39 & 50,65 \\
\hline Indian & 27 & 35,06 \\
\hline Chinese & 8 & 10,39 \\
\hline Etc & 3 & 3,90 \\
\hline \multicolumn{3}{|l|}{ Class } \\
\hline 2016 & 29 & 37,66 \\
\hline 2017 & 20 & 25,97 \\
\hline 2018 & 28 & 36,36 \\
\hline \multicolumn{3}{|l|}{ MIDAS } \\
\hline No disability & 0 & 0 \\
\hline
\end{tabular}




\begin{tabular}{l|ll|} 
Little & 38 & 49,35 \\
Moderate & 34 & 44,16 \\
Severe & 5 & 6,49 \\
\hline
\end{tabular}

Characteristics of respondents found that the average age of respondents was 20.97 years with a standard deviation of 1.42 years. The majority of respondents were 22 years old (20.97\%). Female respondents were found to be greater than men, ie $60(77.90 \%)$ and the majority of 2016 respondents from each faculty were 29 (37.66\%) .Based on racial characteristics, Malay constituted the majority of these characteristics with 39 people with Malay namely $50.65 \%$ and is a portion of the respondents in this study, follow India, China and others. In terms of MIDAS, the majority of those suffering from migraine in this category are 6-10 in 38 (49.35\%), followed by the moderate, and severe categories.

Table 2. Distribution of respondent based on Waist Circumference

\begin{tabular}{l|ll}
\hline $\begin{array}{l}\text { Waist } \\
\text { circumference }\end{array}$ & Frequency (n) & Percentage (\%) \\
\hline Normal & 47 & 61,04 \\
High Risk & 23 & 29,87 \\
Very High Risk & 7 & 9,09 \\
\hline
\end{tabular}

Based on Table 2. Most respondents had normal waist circumference with a number of 47 people $(61.04 \%)$, followed by a high risk waist circumference of 23 people $(29.87 \%)$ and the least with a very high risk waist circumference was 7 people (9.09\%).

Table 3. Distribution of respondents based on pain intensity

\begin{tabular}{l|ll}
\hline Pain Intensity (VAS) & Frequency (n) & Percentage (\%) \\
\hline No pain & 0 & 0 \\
Light & 12 & 15,60 \\
Moderate & 65 & 84,40 \\
Severe & 0 & 0 \\
\hline
\end{tabular}

Based on Table 3. respondents who experienced the most pain intensity were the moderate group as many as 65 people ( $84.4 \%$ ), and followed by the mild group with the number of respondents as many as 10 people $(15.6 \%)$, so on the group that had no pain and severe pain do not have respondents. 
Table 4. Distribution of respondents based on the frequency of migraine attacks

\begin{tabular}{l|ll}
\hline $\begin{array}{l}\text { Frequency } \\
\text { Migraine }\end{array}$ & Frequency $(\mathrm{n})$ & Percentage (\%) \\
\hline 1-4 times & 19 & 24,70 \\
$5-9$ times & 9 & 11,70 \\
$>10$ times & 49 & 63,60 \\
\hline
\end{tabular}

Based on table 4. respondents with the highest frequency of migraine attacks were groups of > 10 times as many as 49 people $(63.60 \%)$, and followed by groups of 1-4 times which is 19 people $(24.70 \%)$, and the last was group 5-9 times the attack that is 9 people $(11.70 \%)$.

Table 5. Relationship between Waist Circumference and Frequency of Migraine attacks

\begin{tabular}{|c|c|c|c|c|c|c|c|c|}
\hline \multirow{2}{*}{\multicolumn{2}{|c|}{ Parameter }} & \multicolumn{6}{|c|}{ Frequency Migraine (n) } & \multirow{3}{*}{$\begin{array}{c}\text { P- } \\
\text { Value }\end{array}$} \\
\hline & & \multicolumn{2}{|c|}{ 1-4 times } & \multicolumn{2}{|c|}{ 5-9 times } & \multicolumn{2}{|c|}{$>10$ times } & \\
\hline & & n & $\%$ & $\mathbf{n}$ & $\%$ & n & $\%$ & \\
\hline \multirow{7}{*}{$\begin{array}{l}\text { Waist } \\
\text { Circum } \\
\text { ference }\end{array}$} & Normal & 11 & 14,3 & 8 & 10,4 & 28 & 36,4 & \\
\hline & & & $\%$ & & $\%$ & & $\%$ & \\
\hline & High & 6 & $7,8 \%$ & 1 & $1,3 \%$ & 16 & 20,8 & \\
\hline & Risk & & & & & & $\%$ & \\
\hline & Very & 2 & $2,6 \%$ & 0 & $0,0 \%$ & 5 & $6,5 \%$ & 0.489 \\
\hline & High & & & & & & & \\
\hline & Risk & & & & & & & \\
\hline \multirow{2}{*}{\multicolumn{2}{|c|}{ Total }} & 19 & $24,7 \%$ & 9 & 11,7 & 49 & 63,6 & \\
\hline & & & & & $\%$ & & $\%$ & 47 \\
\hline
\end{tabular}

Based on Table 5. obtained from 47 respondents (61.0\%) who had normal waist circumference, 28 people had experienced $>10$ migraine attacks (36.4\%), followed by 11 people experienced $1-$ 4 attacks (14.3\%), and only 8 people experienced migraine attacks 5-9 times (10.4\%). Of the 23 respondents $(29.9 \%)$ who had a high risk waist circumference, 16 of them had> 10 migraine attacks $(20.8 \%)$, followed by 6 respondents who had 1-4 attacks $(7.8 \%)$, and 1 people experience 5-9 times a migraine attack (1.3\%). Of the 7 people $(9.1 \%)$ who have a very high waist circumference, 5 of them experienced> 10 migraine attacks $(6.5 \%)$, and the rest experienced 1-4 migraine attacks (2.6\%). Chi-Square test results obtained from the SPSS analysis were $(\mathrm{p}=0.489)$. Therefore, it can be concluded that the relationship between waist circumference and attack frequency does not have a significant relationship. 
Tabel 6. Relationship between Waist Circumference with Pain Intensity

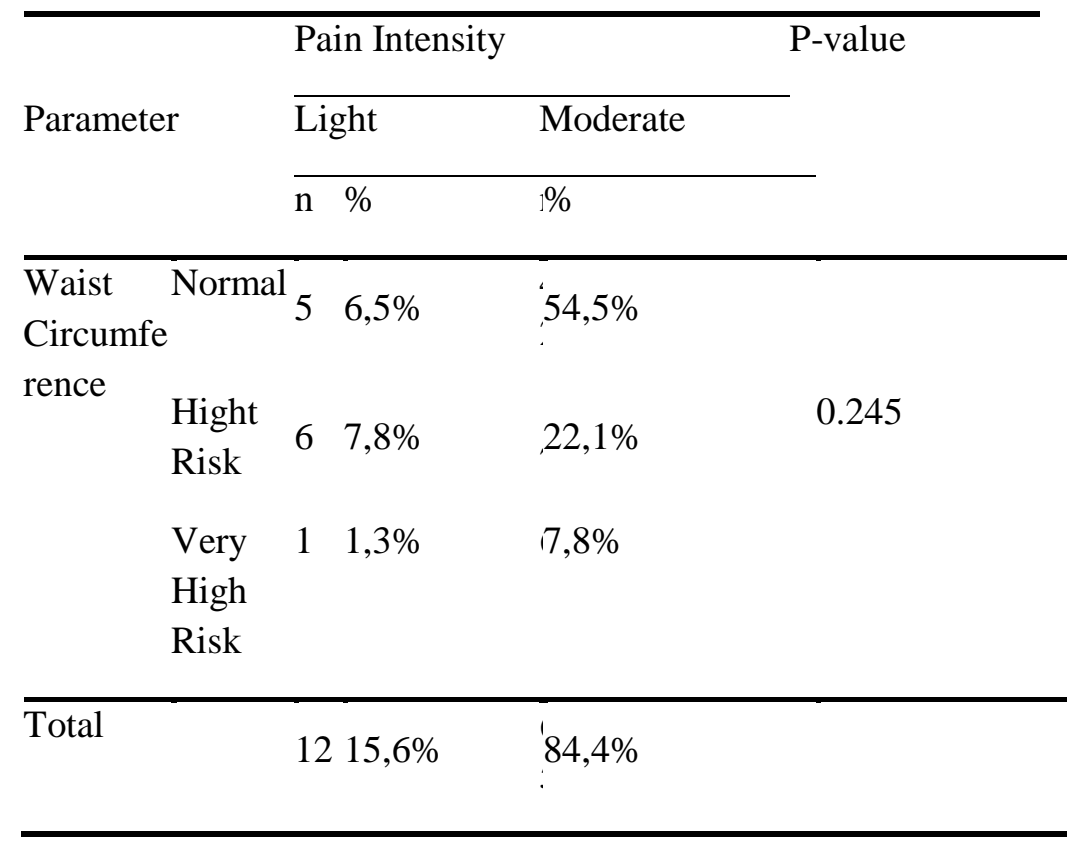

Based on Table 6. obtained, of 47 respondents (61.0\%) who had normal waist circumference, 42 people $(54.5 \%)$ of them experienced moderate pain intensity and 5 people $(6.5 \%)$ of them experienced mild pain . Furthermore, out of 23 respondents $(29.9 \%)$ who had high-waist circumferences, high risk, 17 people $(22.1 \%)$ of them experienced moderate pain intensity and 6 people $(7.8 \%)$ of them experienced mild pain. Of the 7 respondents $(9.1 \%)$ who had a very high waist circumference, 6 people $(7.8 \%)$ of them experienced moderate pain intensity and 1 person (1.3\%) of them experienced mild pain. Chi-Square test results obtained from the SPSS analysis are $(\mathrm{p}=0.245)$. Therefore, it can be concluded that the relationship between waist circumference with pain intensity does not have a significant relationship.

\section{Discussion}

- Frequency Distribution of Characteristics of Respondents

Based on the respondents in this study, there were 77 people (82.0\%) out of a total of 17 men $(22.1 \%)$ and 60 women (77.9\%). Most of the students were 22 years old (26.0\%) with an average age of 20.97 and the majority came from the 2016 canopy as many as 29 people (37.7\%). According to the World Health Organization (WHO) the age limit for teenagers is 12 to 24 years and not yet married. (Goddess, 2012). From the results of waist circumference measurements made using a measuring tape, 47 respondents $(61.0 \%)$ had normal waist circumferences, 23 respondents (29.9\%) had high risk waist circumferences and 7 respondents $(9.1 \%)$ ) have a very high risk in the case group. From the distribution of groups in which the normal group has a waist circumference of less than 80 for women and 90 for the rest of the men have values of more than 80 or 90 .

In the examination and results of the Body Mass Index (BMI) which also plays an important role for the waist circumference where 45 respondents (58.4\%) of all respondents have a normal BMI, 13 respondents (16.9\%) have a BMI underweight, 11 respondents (14.3\%) had an overweight BMI and 8 people (10.4) had an obese BMI. From the normal group distribution having a BMI standard of around $18.5-24.9 \mathrm{~kg} / \mathrm{m} 2$, the rest for underweight has a BMI value of less than $18.5 \mathrm{~kg} / \mathrm{m} 2$, for overweight having a BMI value of more than $24.9 \mathrm{~kg} / \mathrm{m} 2$ and 
obesity have a BMI value that is more than the overweight value which is more than $27 \mathrm{~kg} / \mathrm{m} 2$. From both examinations and results obtained from waist circumference and BMI of all Malaysian students studying at USU, the mean had a normal distribution. The uniqueness of adolescent lifestyles now will cause waist circumference and BMI values to change and will increase the risk of various diseases such as migraine.

In the study Nauman, B, N, et al., 2018 said the relationship between obesity and migraine builds a strong positive relationship between central obesity and migen in a case-control study, their research comparing both types of central obesity and general obesity and showing a significant association of migraine with both types, but especially with central obesity. Many studies have proven that obesity is generally an important risk factor for migraine rather than general obesity. The relationship between obesity and migraine can be explained by many factors: lack of exercise, hypothalamus, lack of lifestyle related to exercise, and psychological factors, morbidity. Adipose tissue, specifically adipose tissue, secretes many inflammatory mediators such as adipokin, tumor necrosis factor $\alpha$, and calcitonin-related peptides, which can trigger migraines, and this may explain the stronger relationship between central obesity and migraine rather than general obesity. [25]

- Relationship of Waist Circumference with Frequency of Migraine attacks

The results of the normality test data using the Kolmogorov-Smirnov test showed that the waist circumference $\mathrm{p}$ value was $0.370>0.05$ meaning the normality of the waist circumference data in this study was normal, while the $\mathrm{p}$ value of the frequency of migraine attacks was $0.370>$ 0.05 which showed that the normality of the result data the frequency of migraine attacks is normal.

The results of statistical analysis using the chi-square test obtained $p$-value $(p=0.489)$ which is more than $(\mathrm{p}<0.05)$, meaning that there is no significant relationship between waist circumference and frequency of migraine attacks by Malaysian students studying at USU. This is not in line with research by Bond, et al., 2012, which has conducted research on the relationship between migraine and obesity and found hypotheses of people who have large waistlines or obesity, have a higher risk of migraine than normal. [23] Adipocytes secrete and produce many substances, including hormones, cytokines (such as interleukin-6), and adipocytokines (such as adiponectin); the amount released by adipocytes varies based on the location of the depot. Thus, the distribution of adipose tissue and the ratio of VAT to SAT in the abdominal region modulates the secretion and production of cytokines and adipocytokines in such a way as to contribute to migraine. [26]

In another study, conducted by Sadeghi, O, et al., 2016 that found a significant positive relationship between WC, WHR, and WHtR with the severity of migraine attacks, frequency of migraine attacks, and HDR, but not the duration of migraine attacks. In addition, migraine patients with high WC have a higher frequency of migraine attacks, compared to patients with normal WC. Losing weight reduces belly fat as well as the severity and frequency of migraine attacks. In addition, obese migraine women have a higher frequency of attacks, photophobia, and phonophobia than non-obese migraine women. [27]

- Relationship of Waist Circumference with Pain Intensity (VAS)

The results of normality test data using the Kolmogorov-Smirnov test showed that the waist circumference $\mathrm{p}$ value was $0.370>0.05$ meaning normality of the waist circumference data in this study was normal, while the $\mathrm{p}$ value of the Vas Score was $0.478>0.05$ which indicated that the normality of the intensity intensity data migraine pain is normal. 
The results of statistical analysis using the chi-square test obtained $p$-value $(\mathrm{p}=0.245)$ which is more than ( $\mathrm{p}<0.05)$, meaning that there is no significant relationship between waist circumference with the intensity of migraine pain by Malaysian students studying at USU. This is not in line with research conducted by Afshinmajd, S., 2011 who has conducted research and the results are 203 patients completed the study. 153 (75\%) subjects were female and $50(25 \%)$ were male. The mean age of the patients was $30.5 \pm 7.1$ years. The average weight was $80.4 \pm$ $14.1 \mathrm{~kg}$ and the average height was $1.67 \pm 0.07 \mathrm{~m}$. The frequency and duration of pain showed statistically significant differences between the four groups with better response in patients with lower BMI (P <0.0001). The VAS and BRS-6 scales showed statistically significant differences between the four groups supporting patients with lower BMI $(\mathrm{P}<0.0001)$. [11]

In another study, conducted by Bond, D, et al., 2016 using different pain intensity methods, stated that all participants predicted migraine characteristics from the total PCS score, controlling BMI. Higher total PCS scores were independently associated with more migraine days $(\beta=0.331, p=0.001)$, longer attack duration $(\beta=0.390, p<0.001)$, higher HIT-6 scores $(\beta$ $=0.425, \mathrm{p}<0.001)$, and lower HMSE scores $(\beta=, 40.437, \mathrm{p}<0.001)$. A higher BMI, but not a higher PCS score, was associated with more frequent attacks $(\beta=-0.203, p=0.044)$. [28]

\section{Conclusion}

1. The results of the Chi Square analysis show there is no relationship between the Waist Circumference with the Frequency of Attack of Malaysian students who migraine studies at the University of North Sumatra.

2. The results of the Chi Square analysis show there is no relationship between the Waist Circumference with the Pain Intensity of Malaysian students who migraine studies at the University of North Sumatra

\section{REFERENCES}

1. Korelasi lingkar pinggang dan rasio lingkar pinggang-panggul terhadap kadar glukosa plasma menggunakan tes toleransi glukosa oral. Rokhmah, Farida Dwi, Handayani, Dian and Al-Rasyid, Harun. Malang : Jurnal Gizi Klinik Indonesia, 2015, Jurnal Gizi Klinik Indonesia, Malang, Vols. 12(1) pp 28-35, pp. pp 28-35.

2. Gambaran Rasio Lingkar Pinggang Pinggul, Riwayat Penyakit Dan Usia Pada Pegawai Polres Pekanbaru. Harahap, Muharni and Mochta, Yusrizal. Pekanbaru : Jurnal Kesehatan Masyarakat Andalas, 2016, Jurnal Kesehatan Masyarakat Andalas, Pekanbaru, Vol. 10(2), pp. p 140-141.

3. Prevalence of Obesity in the United States, 2009-2010. Ogden, Cynthia L, et al., et al. Hyattsville, USA : National Center for Health, 2012, Nation Centre Of Health, Hyattsville, Vol. 12(84).

4. Riset Kesehatan Dasar. Balitbangkes. Jakarta: Kementerian Kesehatan Republik Indonesia, 2013, Kementerian Kesehatan Republik Indonesia, Jakarta, pp. pp 225-227.

5. Waist circumference of healthy men and women in the United States. Flegal, KM . Maryland, Columbia: Nature Publishing Group, 2007, Nature Publishing Group, Maryland, Vol. 31 , pp. pp 1134-1139.

6. Faktor Risiko Overweight Dan Obese Pada Orang Dewasa Di Indonesia. Sudikno, et al., et al. Bogor : Gizi Indonesia, 2015, Gizi Indonesia, Bogor, Vol. 38 ed, pp. pp 1-2.

7. Impact of an Intensive Lifestyle Intervention on Use and Cost of Medical Services Among Overweight and Obese Adults With Type 2 Diabetes: The Action for Health in 
Diabetes. Espeland, Mark A, et al., et al. Chicago : American Diabetes Association, 2014, American Diabetes Association, Chicago, Vol. 37 , pp. pp 2548-2549.

8. Obesity is a Risk Factor for Transformed Migraine but not Chronic Tension-Type Headache. Bigal, Marcelo E and Lipton, Richard B. New York: American Academy of Neurology, 2012, American Academy of Neurology, New York, Vol. 67, pp. pp 1-3.

9. Faktor-Faktor Yang Berhubungan Dengan Sindrom Metabolik Pada Penderita Rawat Jalan Di Rsud Ulin Banjarmasin. Magdalena, Mahpolah and Yusuf, Alfian. Banjarmasin : Jurnal Skala Kesehatan, 2014, Jurnal Skala Kesehatan, Banjarmasin, Vol. volume 5(2), pp. pp 1-3.

10. Migraine, Weight Gain and the Risk of becoming Overweight or Obese. Winter, Anke C, et al., et al. Boston : National Institute of Health, 2013, National Institutes of Health, Boston, Vol. 32(13), pp. pp 1-3.

11. The effects of body mass index on the treatment of the patients with migraine headaches. Afshinmajd, Siamak, Davati, Ali and Akbari, Farnaz . Tehran, Iran : Iranian Journal of Neurology, 2011, Iranian Journal of Neurology, Tehran, Vols. 10(3-4) , pp. 35-38.

12. Nyeri Kepala "Rhinogenic". Setiawan, Indra. Malang: Jurnal Ilmi Kesehatan dan Kedokteran Keluarga, 2014, Jurnal Ilmu Kesehatan dan Kedokteran Keluarga, Malang, Vol. 10.

13. Faktor-Faktor Penyebab Dan Jenis Migrain Pada Mahasiswa Fakultas Keperawatan Unversitas Syiah Kuala Tahun 2014. Bahri, Teuku Samsul and Zulfazli. Aceh: Fakultas Keperawatan Universitas Syiah Kuala, 2014.

14. Penatalaksanaan Migren. Anurogo, Dito. Palangkaraya, kalimantan tengah : CDK-198, 2012, CDK-198, Palangkaraya, Vol. 39(10).

15. Korelasi Antara Migrain Dengan Kejadian Stroke. Utami, Melati Nurul, Oktarlina, Rasmi Zakiah and Himayani, Rani. Lampung : medula, 2017, Medula, Lampung, Vol. 7(4).

16. Disability, ICF Biopsychosocial Mode; and Burden of Migraine. Leonardi, Matilde, et al., et al. Milan,Italy: The Journa of Headache and Pain, 2015, The Journal of Headache and Pain, Milan, Vol. 16(1).

17. The socioeconomic impact of migraine. Chandler, James, et al., et al. Portland, United Kingdom : The Work Foundation, 2018, The Work Foundation, Portland.

18. Men, women, and migraine: The role of sex, hormones, obesity, and PTSD. Peterlin, B Lee, Calhoun, Anne H and Balzac, Fred. United State : The Journal Of Family Practice, 2012, The Journal of Family Practice, USA, Vol. 61(4).

19. CGRP and Mirgraine: Neurogenic Inflammation Revisited. Geppetti, Pierangelo, et al., et al. Florence, Italy : J Headache Pain, 2005, J Headache Pain, Florence, Vol. 6, pp. pp 61-70.

20. Korelasi Antara Migraine Dengan Kejadian Stroke. Utami, Melati Nurul, Oktarlina, Rasmi Zakiah and Himayani, Rani. Lampung: Medula, 2017, Medula, Lampung, Vol. 7(4), pp. pp 41-43.

21. Body mass index and migraine: a survey of the Chinese adult population. $\mathrm{Yu}$, Shengyuan, et al., et al. Beijing : J Headache Pain, 2012, J Headache Pain, Beijing, Vol. 13 , pp. pp 531-536.

22. Migraine and Obesity: epidemiology, possible mechanisms and the potential role of weight loss treatment. Bond, D S, et al., et al. Rhode Island: National Institude of Health, 2012, National Institude of Health, Rhode Island, Vol. 12(501), pp. 1-5.

23. Migraine and obesity: epidemiology, possible mechanisms and the potential role of weight loss treatment. Bond, D S, et al., et al. Rhode Island, USA : National Institute of Health, 2012, National Institute of Health, Rhode Island, Vol. 12(501), pp. pp 1-5. 
24. Migraine is Strongly Associatedwith Central Obesity Than with General Obesity:A Case-Control Study. Nauman, Bilal Natiq and Sadik, M Asaad. Iraqa : Turkish Journal of Endocrinology and Metabolism Association, 2018, Turkish Journal of Endocrinology and Metabolisme Association, Iraqa, Vol. 23, pp. 25-32.

25. Strategic Guidance on Accelerating Actions for Adolescent Health in South-East Asia Region (2018-2022). New Delhi: World Health Organization, Regional Offi ce for South-East Asia; 2018. Licence: CC BY-NC-SA 3.0 IGO. Available from : http://apps.who.int/iris

26. Obesity and Migraine: The Effect of Age, Gender and Adipose Tissue Distribution. Peterlin, B Lee, et al., et al. Philadelphia : National Institute of Health, 2013, National Institude of Health, Philadelphia, Vol. 50(1), pp. 51-62.

27. The association between abdominal obesity and characteristics of migraine attacks in Iranian adults. Sadeghi, Omid, Askari, Gholamreza and Khorvash, Fariborz. Isfahan, Iran : Iranian Journal of Nursing and Midwifery Research, 2016, Iranian Journal of Nursing and Midwifery Research, Vol. 21(3), pp. pp 271-277.

28. Clinical Pain Catastrophizing in Women with Migraine and Obesity. Bond, Dale S., et al., et al. New York : Health and Human Services, 2016, Health and Human Services, Vol. 55(7), pp. 923-933. 